\title{
Effect of a viable yeast culture on digestibility and rumen fermentation in sheep fed different types of diets
}

\author{
LO Fiems ${ }^{1 *}$, BG Cottyn 1, L Dussert 2, JM Vanacker 1 \\ 1 National Institute for Animal Nutrition, Agricultural Research Centre - Ghent Scheldeweg 68, \\ B-9090 Melle-Gontrode, Belgium \\ 2 SI Lesaffre, 137 Rue Gabriel Péri, F-59703 Marcq-en-Baroeul, France
}

(Received 15 May 1992; accepted 29 October 1992)

\begin{abstract}
Summary - Five mature wethers fitted with rumen fistulas were fed grass hay and a sugarbeetpulp-based concentrate or maize silage and a cereal-based concentrate (50/50 digestible organic matter basis), or without with $5 \mathrm{~g}$ yeast supplement (Saccharomyces cerevisiae, Biosaf(i) per day in a latin square design. Diets were given for a $28-d$ adaptation period, followed by a 10-d collection period to determine digestibility and nitrogen retention data. Afterwards, rumen samples were taken on 3 consecutive days and analysed for volatile fatty acids, $\mathrm{pH}$ and ammonia.

Digestibility and nitrogen balance were not affected by yeast treatment. Supplementation of yeast increased acetate: propionate ratio, butyrate, isoacids, $\mathrm{pH}$ and ammonia. The effects were more pronounced for the maize silage diet. These results demonstrate that the effect of yeast culture on rumen fermentation may depend on the nature of the diet.

Living yeast cell number in the rumen fluid rapidly declined when dietary yeast was ceased. Furthermore, yeast cells survived the passage through the digestive tract.
\end{abstract}

yeast / rumen fermentation / volatile fatty acids / sheep

Résumé - Effet d'une levure vivante sur la digestibilité et la fermentation dans le rumen des moutons recevant différents types de ration. Cinq béliers châtrés fistulés ont rệu une ration à base de foin et de concentré riche en pulpe de betteraves sucrières ou de l'ensilage de maïs et du concentré riche en céréales (50/50 sur la base de la matière organique digestible), complémentée ou non avec $5 \mathrm{~g}$ de levure (Biosaf()) / j suivant un schéma en carré latin. Les régimes ont été distribués pendant une période d'adaptation de $28 \mathrm{j}$, suivie d'une période de collecte de $10 j$, afin de déterminer la digestibilité et les bilans d'azote. Ensuite, des échantillons du contenu du rumen ont été prélevés pendant $3 j$ consécutifs pour déterminer les acides gras volatils, le pH et l'ammoniaque. La digestibilité et les bilans d'azote n'ont pas été influencés par la levure, tandis que la proportion acétate/propionate, les concentrations de butyrate et d'ammoniaque et le pH ont été augmentés. L'effet a été plus net avec la ration d'ensilage de maiss. Ces résultats démontrent que l'effet de la levure dé-

* Correspondence and reprints 
pend du type de ration. Le nombre des cellules vivantes de levures au niveau du rumen a diminué quand l'administration de levure a cessé. Le dénombrement des cellules vivantes dans les fécès a démontré que les levures peuvent survivre tout au long du tractus digestif de l'animal.

levure / fermentation dans le rumen / acide gras volatil/mouton

\section{INTRODUCTION}

Recently, there has been remarkable interest in the use of yeast cultures to improve productivity in livestock husbandry. In comparison with antimicrobial agents, yeast culture offers a natural alternative to manipulate animal performance.

Positive effects of a yeast culture on performances of dairy cows and rearing calves have been reported (Günther, 1989; Gomez-Alarcon et al, 1991 and Williams et al, 1991).

However, a significant positive effect of yeast on animal performance was not always confirmed (Adams et al, 1981; Fallon and Harte, 1987; Gomez-Alarcon et al, 1991; Williams et al, 1991). Therefore, the mode of action of a yeast culture needs to be unravelled to explain the variable response to yeast supplementation.

The purpose of this study was to evaluate the effect of yeast culture on digestibility and rumen fermentation in 2 different types of diets, and to investigate the survival of yeast cells in the digestive tract.

\section{MATERIALS AND METHODS}

Digestibility coefficients and ruminal fermentation characteristics were determined with 5 ruminally cannulated wethers, receiving a diet composed of $50 \%$ grass hay and $50 \%$ concentrate (diet $A$ ) or $50 \%$ maize silage and $50 \%$ concentrate (diet $\mathrm{B}$ ) on a digestible organic matter (DM) basis. The concentrates were formulated to contain a low or a high content of rapidly fermentable carbohydrates, respectively, and to yield a $12 \%$ crude protein content in the dry matter of the diets. The percentage composition of the 2 concentrates is given in table I. Each diet was fed at maintenance in 2 meals daily, without (control, C) or with $2.5 \mathrm{~g}$ yeast ( $Y$, Saccharomyces cerevisiae) (Biosa ${ }^{(\mathbb{B}}$, SI Lesaffre, France) per meal. The experiment was carried out according to a $4 \times 4$ latin square design.

Each collection period lasted $10 \mathrm{~d}$ and was preceded by an adaptation period of $28 \mathrm{~d}$. Faeces and urine were collected to determine apparent nutrient digestibility and nitrogen $(\mathrm{N})$ retention. Analyses of feeds and faeces were conducted according to standard methods. After the collection period, rumen liquid samples were taken on 3 consecutive days at $2 \mathrm{~h}$ postprandial to measure $\mathrm{pH}$, volatile fatty acid (VFA) concentration and ammonia. VFA's were determined by gas chromatography (Supelco, 1991). Ammonia was analysed according to the method of Voigt and Steger (1967).

Digestibility and fermentation data were presented as means, using a 2-way analysis of variance to detect differences (Snedecor and Cochran, 1980).

At the end of the yeast administration rumen samples were taken from 3 animals per diet at the time of the last feeding of $Y$ and at 2 and $8 \mathrm{~h}$ after this meal. Furthermore, rumen samples were also taken after 24,32 and $48 \mathrm{~h}$ only from 2 animals, one on each diet.

Faeces samples were taken from the same animals at $2 \mathrm{~h}$ after the last feeding of $\mathrm{Y}$ and after 24 and $48 \mathrm{~h}$. One animal, fed the control diet, was also investigated. Because of the negligible amount of yeast cells in the rumen fluid no further measurements were carried out. The number of viable yeast cells in rumen fluid and faeces was determined by counting the colony forming units on YM agar (Difco) containing 1\% chloramphenicol. 
Table I. Composition of the experimental concentrates and chemical analysisof the feeds.

\begin{tabular}{|c|c|c|c|c|}
\hline & \multicolumn{2}{|c|}{ Diet $A$} & \multicolumn{2}{|c|}{ Diet $B$} \\
\hline & Concentrate & Grass-hay & Concentrate & Maize silage \\
\hline \multicolumn{5}{|l|}{ Ingredients (\%) } \\
\hline Sugarbeet pulp & 96.3 & - & - & - \\
\hline Wheat & - & - & 43 & - \\
\hline Barley & - & - & 43 & - \\
\hline Soybean meal & - & - & 9.4 & - \\
\hline Mineral-vitamin premix & 3.7 & - & 4.6 & - \\
\hline \multicolumn{5}{|c|}{ Chemical analysis (g/kg DM) } \\
\hline Dry matter & 865 & 824 & 860 & 362 \\
\hline Crude protein & 107 & 157 & 157 & 69 \\
\hline Ether extract & 5 & 17 & 14 & 26 \\
\hline Crude fibre & 201 & 270 & 45 & 210 \\
\hline $\mathrm{N}$-free extract & 643 & 485 & 739 & 650 \\
\hline Total ash & 44 & 71 & 45 & 45 \\
\hline Sugars & 59 & 95 & 29 & 5 \\
\hline Starch & - & 6 & 535 & 331 \\
\hline
\end{tabular}

\section{RESULTS}

The chemical composition of the feeds is shown in table I. Due to the rather low protein content of maize silage $(69 \mathrm{~g} / \mathrm{kg} \mathrm{DM})$, the diets were not exactly isonitrogenous. They contained 133 and $110 \mathrm{~g}$ crude protein per $\mathrm{kg} \mathrm{DM}$, respectively. Starch content of diet $\mathrm{B}$ averaged $426 \mathrm{~g}$ per $\mathrm{kg} \mathrm{DM}$, while it was negligible in $\operatorname{diet} A$.

Apparent digestibility coefficients (table II) were not significantly affected by yeast addition. Diet type exerted a significant effect on organic matter, ether extract and crude fibre. Organic matter $(P=0.07)$ and crude fibre $(P<0.001)$ were better digested in diet $A$ than in diet $B$.

Nitrogen balance data are presented in table III. They were not affected by diet type or yeast treatment.

The inclusion of yeast in the diet provoked a more pronounced effect on ruminal fermentation characteristics than on nutrient digestibility (table IV). Total VFA concentration was not modified. However, molar concentrations of butyric, isobutyric and isovaleric acid were increased by $\mathrm{Y}$, while propionic acid concentration was reduced. Isoacids (branched VFA and valeric acid) were slightly but non significantly increased by yeast. Furthermore, $\mathrm{pH}$ and ammonia concentration were higher for $Y$ than for $C$ treatment.

Most fermentation parameters also differed between diets $\mathrm{A}$ and $\mathrm{B}$. Only $\mathrm{pH}$ was similar for both diets.

The number of viable yeast cells remained at $\approx 10^{5}-10^{6}$ per $\mathrm{ml}$ rumen fluid for at least $8 \mathrm{~h}$. After $48 \mathrm{~h}$ the number decreased to a negligible amount of $3.10^{2}$ cells per $\mathrm{ml}$.

In the faeces a concentration of $10^{5}-10^{6}$ yeast cells per $\mathrm{g}$ was found after $8 \mathrm{~h}$. However, yeast cell number decreased more slowly in the faeces than in the rumen and amounted to $15.10^{3}$ after $48 \mathrm{~h}$. 
Table II. Effect of diet and yeast culture on nutrient digestibility (\%).

\begin{tabular}{|c|c|c|c|c|c|c|c|c|}
\hline & \multicolumn{2}{|c|}{$\operatorname{Diet} A$} & \multicolumn{2}{|c|}{ Diet B } & \multirow{2}{*}{$\begin{array}{l}\text { Pooled } \\
\text { SE }\end{array}$} & \multicolumn{3}{|c|}{ Significance } \\
\hline & $C$ & $Y$ & $c$ & $Y$ & & $\begin{array}{c}\text { Yeast } \\
\mathbf{P}\end{array}$ & $\begin{array}{c}\text { Diet } \\
\mathrm{P}\end{array}$ & $\begin{array}{c}\text { Interaction } \\
\mathrm{P}\end{array}$ \\
\hline Dry matter & 76.9 & 76.8 & 75.9 & 75.1 & 1.9 & $>0.1$ & $>0.1$ & $>0.1$ \\
\hline Organic matter & 79.3 & 79.1 & 77.7 & 77.1 & 1.9 & $>0.1$ & $=0.07$ & $>0.1$ \\
\hline Crude protein & 65.4 & 65.0 & 67.6 & 66.1 & 4.0 & $>0.1$ & $>0.1$ & $>0.1$ \\
\hline Ether extract & 0.0 & 0.0 & 79.1 & 78.4 & 4.6 & $>0.1$ & $<0.001$ & $>0.1$ \\
\hline Crude fibre & 80.4 & 79.6 & 53.9 & 52.2 & 4.3 & $>0.1$ & $<0.001$ & $>0.1$ \\
\hline $\mathrm{N}$-free extract & 83.8 & 83.8 & 83.9 & 83.6 & 1.3 & $>0.1$ & $>0.1$ & $>0.1$ \\
\hline Gross energy & 74.6 & 74.7 & 75.7 & 74.7 & 1.9 & $>0.1$ & $>0.1$ & $>0.1$ \\
\hline
\end{tabular}

Table III. Effect of diet and yeast culture on nitrogen (N) balance.

\begin{tabular}{|c|c|c|c|c|c|c|c|c|}
\hline & \multicolumn{2}{|c|}{ Diet $A$} & \multicolumn{2}{|c|}{ Diet $B$} & \multirow{2}{*}{$\begin{array}{c}\text { Pooled } \\
\text { SE }\end{array}$} & \multicolumn{3}{|c|}{ Significance } \\
\hline & $c$ & $Y$ & $c$ & $Y$ & & $\begin{array}{c}\text { Yeast } \\
\mathrm{P}\end{array}$ & $\begin{array}{c}\text { Diet } \\
\mathrm{P}\end{array}$ & $\begin{array}{c}\text { Interaction } \\
\mathrm{P}\end{array}$ \\
\hline $\begin{array}{l}\mathrm{N} \text { Intake (g/day) } \\
\text { Fecal N (\%) } \\
\text { Absorbed N (\%) } \\
\text { Urinary N }(\%) \\
\text { Retained N (\%) }\end{array}$ & $\begin{array}{r}139.9 \\
34.6 \\
65.4 \\
51.8 \\
13.6\end{array}$ & $\begin{array}{r}142.7 \\
35.0 \\
65.0 \\
49.6 \\
15.4\end{array}$ & $\begin{array}{r}125.3 \\
32.4 \\
67.6 \\
48.2 \\
19.4\end{array}$ & $\begin{array}{r}117.0 \\
33.9 \\
66.1 \\
52.7 \\
13.4\end{array}$ & $\begin{array}{r}12.5 \\
4.0 \\
4.0 \\
7.3 \\
6.5\end{array}$ & $\begin{array}{l}>0.1 \\
>0.1 \\
>0.1 \\
>0.1 \\
>0.1\end{array}$ & $\begin{array}{l}<0.01 \\
>0.1 \\
>0.1 \\
>0.1 \\
>0.1\end{array}$ & $\begin{array}{l}>0.1 \\
>0.1 \\
>0.1 \\
>0.1 \\
>0.1\end{array}$ \\
\hline
\end{tabular}

Table IV. Effect of diet and yeast culture on rumen fermentation characteristics.

\begin{tabular}{|c|c|c|c|c|c|c|c|c|}
\hline & \multicolumn{2}{|c|}{ Diet A } & \multicolumn{2}{|c|}{ Diet B } & \multirow{2}{*}{$\begin{array}{c}\text { Pooled } \\
\text { SE }\end{array}$} & \multicolumn{3}{|c|}{ Signifiance } \\
\hline & $c$ & $Y$ & $c$ & $Y$ & & $\begin{array}{l}\text { Yeast } \\
\mathrm{P}\end{array}$ & $\begin{array}{c}\text { Diet } \\
\mathrm{P}\end{array}$ & $\begin{array}{c}\text { Interaction } \\
\mathbf{P}\end{array}$ \\
\hline Volatile fatty acids & 11.32 & 11.53 & 10.02 & 9.49 & 1.40 & $>0.1$ & $<0.001$ & $>0.1$ \\
\hline Acetic acid & 67.31 & 67.97 & 58.18 & 58.93 & 2.37 & $>0.1$ & $<0.001$ & $>0.1$ \\
\hline Proprionic acid & 20.93 & 20.32 & 26.94 & 22.39 & 2.95 & $<0.001$ & $<0.001$ & $<0.01$ \\
\hline Butyric acid & 8.97 & 8.85 & 10.68 & 14.06 & 1.64 & $<0.001$ & $<0.001$ & $<0.001$ \\
\hline Isobutyric acid & 0.79 & 0.86 & 0.86 & 1.44 & 0.50 & $<0.05$ & $<0.05$ & $<0.05$ \\
\hline 2-Methylbutyric acid & 0.31 & 0.34 & 0.57 & 0.58 & 0.24 & $>0.1$ & $<0.001$ & $>0.1$ \\
\hline Valeric acid & 1.32 & 1.28 & 1.92 & 1.56 & 0.68 & $>0.1$ & $<0.05$ & $>0.1$ \\
\hline Isovaleric acid & 0.36 & 0.38 & 0.66 & 1.03 & 0.14 & $<0.001$ & $<0.001$ & $<0.001$ \\
\hline Caproic acid & 0.00 & 0.01 & 0.18 & 0.00 & 0.19 & $=0.09$ & $=0.09$ & $=0.06$ \\
\hline Isoacids & 2.78 & 2.86 & 4.01 & 4.61 & 0.91 & $>0.1$ & $<0.001$ & $>0.1$ \\
\hline Acetate : propionate & 3.22 & 3.36 & 2.25 & 2.67 & 0.36 & $<0.01$ & $<0.001$ & $=0.09$ \\
\hline $\mathrm{pH}$ & 5.97 & 6.03 & 5.78 & 6.15 & 0.28 & $<0.01$ & $>0.1$ & $<0.05$ \\
\hline $\mathrm{NH}_{3}(\mathrm{mg} / 100 \mathrm{ml})$ & 30.06 & 30.76 & 25.77 & 44.96 & 8.19 & $<0.001$ & $<0.05$ & $<0.001$ \\
\hline
\end{tabular}


The evolution of yeast cell number is shown in figure 1. For the one animal on the control diet, only 20 yeast cells were found per $\mathrm{ml}$ rumen fluid.

\section{DISCUSSION}

The lack of an effect of yeast culture on digestibility is in accordance with the experiments of Harrison et al (1988) and Oellermann et al (1990).

However, Wiedmeier et al(1987) reported an increased digestibility. This result can be explained by the incorporation of more structural carbohydrates with a low digestibility in their experimental diets ( $15 \%$ barley straw, $8.5 \%$ wheat bran). It may suggest a positive effect of yeast on digestibility of poor-quality roughages.

Nitrogen balance data were not affected in our experiment. They were in accordance with the results of Edwards et al (1990), obtained with intensively fed bulls.

The inclusion of a yeast culture had a significant effect on the rumen fermentation characteristics. However, these results were not always in agreement with those from other experiments. Yeast increased acetate: propionate ratio, and the concentrations of butyrate and isoacids and am-

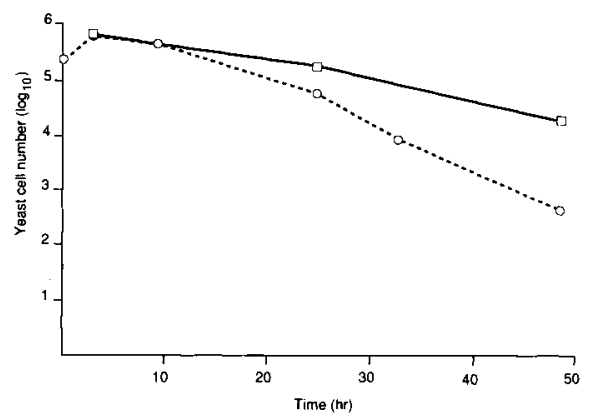

Fig 1. Evolution of yeast cell number per $\mathrm{ml}$ rumen fluid ( $O$ ) and per $\mathrm{mg}$ taeces $(\square)$ atter yeast supplementation. monia similar to the results obtained previously with Rusitec (Frumholtz et al, 1989). The higher $\mathrm{pH}$ in our experiment was not confirmed by Frumholtz et al (1989) and Carro et al (1992), although they reported an elimination of the drop in $\mathrm{pH}$ after addition of feed in comparison with control vessels. From other experiments it was reported that yeast culture had no effect on $\mathrm{pH}$ or VFA concentrations and ammonia (Fondevila et al, 1990; Oellermann et al, 1990). Ammonia was not affected when yeast was added to high fibre diets, but yeast yielded less ammonia in low fibre diets (Moloney, 1989). According to Martin et al (1989) ammonia production on yeastsupplemented diets may depend on substrate. Harrison et al (1988) found that yeast reduced rumen $\mathrm{pH}$, and acetate: proprionate ratio and ammonia concentration, but isoacids were increased in cows. Newbold et al (1990) reported a higher $\mathrm{pH}$, less acetate, more propionate and less ammonia when a yeast culture was fed.

A higher rumen $\mathrm{pH}$ can be partly explained by a lower lactate concentration in yeast supplemented animals (Fondevila et al, 1990; Newbold et al, 1990). Gedek et al (1992) found more amylolytic bacteria in the rumen of dairy cows which received yeast. As they can utilize lactate, the decrease of $\mathrm{pH}$ can be prevented by yeast treatment.

Our results (table IV) demonstrated significant interactions between yeast treatment and diet type for some fermentation parameters. Therefore, the diverging effect of yeast culture on rumen fermentation, reported in the literature, may be a consequence of the differences in the nature of the diets used. Williams and Newbold (1990) suggested that the effect of a yeast culture may be associated with the amount of rapidly fermentable carbohydrates in the diets. Diets with high contents of these carbohydrates depress rumen $\mathrm{pH}$. A depressed rumen $\mathrm{pH}$ may reduce cellulolysis (Mould et al, 1983). 
An increased yeast cell number in the rumen fluid (fig 1) is necessary to enable an alteration of rumen fermentation and digestibility. However, total tract digestibility was not affected (table II), while rumen fermentation was differently modified according to the diet (table IV). The results also show that yeast cannot colonize, but only transit through the rumen. The difference between rumen fluid and faeces with regard to the decline of the number of yeast cells is due to the rate of passage. This observation is in agreement with the declining number of viable yeast cells $(0.17 / \mathrm{h})$, as shown in the experiments of Newbold et al (1990). The reduction of yeast number in the rumen does not necessarily exclude the possibility of a metabolic activity.

Furthermore, the fact that yeast cells can survive the passage through the digestive tract neither excludes a postruminal effect. A survival of Aspergillus oryzae and Saccharomyces cerevisiae in the duodenal digesta was reported by Wanderley et al (1985) and Newbold et al (1990), respectively. For this reason, a probiotic effect cannot be excluded.

\section{CONCLUSION}

This experiment showed no effect of the dietary inclusion of yeast culture on apparent nutrient digestibility. However, there was a significant effect on rumen metabolites.

Furthermore, the interaction between yeast treatment and the nature of diet, found in this study, can help to explain the variable response to yeast culture reported in the literature.

\section{ACKNOWLEDGMENTS}

The authors are grateful to $N$ De Paepe, M Martens, L Roels and J Galle for their skilled technical assistance.

\section{REFERENCES}

Adams DC, Galyean ML, Kiesling HE, Wallace JD, Finkner MD (1981) Influence of viable yeast culture, sodium bicarbonate and monensin on liquid dilution rate, rumen fermentation and feedlot performance of growing steers and digestibility in lambs. $J$ Anim Sci $53,780-789$

Carro MD, Lebzien P, Rohr K (1992) Influence of yeast culture on the in vitro fermentation (Rusitec) of diets containing variable portions of concentrates. Anim Feed Sci Technol 37, 209-220

Edwards IE, Mutsvangwa T, Topps JH, Paterson GFM (1990) The effect of supplemental yeast culture (Yea-sacc) on patterns of rumen fermentation and growth performance of intensively fed bulls. Anim Prod 50, 579 (Abstr)

Fallon RJ, Harte FJ (1987) The effect of yeast culture inclusion in the concentrate diet on calf performance. $J$ Dairy Sci 71 , Suppl 1 , 143 (Abstr)

Fondevila $\mathrm{M}$, Newbold $\mathrm{Cl}$, Hotten PM, Ørskov ER (1990) A note on the effect of Aspergillus oryzae fermentation extract on the rumen fermentation of sheep given straw. Anim Prod 51, 422-425

Frumholtz PP, Newbold CJ, Wallace RJ (1989) Influence of Aspergillus oryzae fermentation extract on the fermentation of a basal diet in the rumen simulation technique (Rusitec). J Agric Sci Camb 113, 169-172

Gedek B, Ahrens F, Roques C (1992) The effect of Saccharomyces cerevisiae (Biosa $\left.{ }^{(}\right)$) on rumen microbial flora and rumen fermentation pattern of dairy cows. Reprod Nutr Dev (in press)

Gomez-Alarcon RA, Huber JT, Higginbotham GE, Wiersma F, Ammon D, Taylor B (1991) Influence of feeding Aspergillus oryzae fermentation extract on the milk yields, eating pattern, and body temperatures of lactating cows. J Dairy Sci 69, 1733-1740

Günther KD (1989) Yeast culture's success under German dairy conditions. In: Biotechnology in the Feed Industry (Lyons TP, ed) Alltech Technical Publications, 39-46

Harrison GA, Hemken RW, Dawson KA, Harmon RJ, Barker KB (1988) Influence of addition of yeast culture supplement to diets of 
lactating cows on ruminal fermentation and microbial populations. J Dairy Sci 71, 29672975

Martin SA, Nisbet DJ, Dean RG (1989) Influence of a commercial yeast supplement on the in vitro ruminal fermentation. Nutr Rep int 40, 395-403

Moloney AP (1989) Rumen fermentation of two contrasting diets with or without the inclusion of yeast culture. Ir J Agric Res 28, 102 (Abstr)

Mould FL, Ørskov ER, Mann SO (1983) Associative effects of mixed feeds. I. Effects of type and level of supplementation and the influence of the rumen fluid $\mathrm{pH}$ on cellulolysis in vivo and dry matter digestion of various roughages. Anim Feed Sci Technol 10, 15-30

Newbold CJ, Williams PEV, McKain N, Walker A, Wallace RJ (1990) The effect of yeast culture on yeast numbers and fermentation in the rumen of sheep. Proc Nutr Soc 49, 47A

Oellermann SO, Arambel MJ, Kent BA, Walters JL (1990) Effect of graded amounts of Aspergillus oryzae fermentation extract on ruminal characteristics and nutrient digestibility in catthe. J Dairy Sci 73, 2413-2416

Snedecor GW, Cochran WG (1980) Statistical Methods. lowa State University Press, Ames IA, 7th ed, $507 \mathrm{p}$
Supelco Inc (1991) Bellafonte PA, Cat No 1, $1825,115 \mathrm{p}$

Voight J, Steger H (1967) Zur quantitativen Bestimmung von Ammoniak, Harnstoff und $\mathrm{Ke}$ tokörpern in biologischen Material mit Hilfe eines modifizierten Mikrodiffusionsgefässes. Arch Tieremährg 17, 289-293

Wanderley RC, Huber JT, Theurer CB, Poore M (1985) Ruminal digestion of protein and fiber in duodenally cannulated cows treated with Vitaferm. J Dairy Sci 68, suppl 1: 123 (Abstr)

Wiedmeier RD, Arambel MJ, Walters JL (1987) Effect of yeast culture and Aspergillus oryzae fermentation extract on ruminal characteristics and nutrient digestibility. J Dairy Sci 70 , 2063-2068

Williams PEV, Newbold CJ (1980) Rumen probiosis: the effects of novel microorganisms on rumen fermentation and ruminant productivity. In: Recent Advances in Animal Nutrition (Haresign W, Cole DJA, eds) Butterworths, 211-227

Williams PEV, Tait CAG, Innes GM, Newbold CJ (1991) Effects of the inclusion of yeast culture (Saccharomyces cerevisiae plus growth medium) in the diet of dairy cows on milk yield and forage degradation and fermentation patterns in the rumen of steers. J Anim Sci 69, 3016-3026 